\title{
Tělesné složení a symetrie těla předních českých zápasníků
}

\section{Body composition and symmetry of the body of the top Czech wrestlers}

\author{
Klára Coufalová, Jan Heller \\ Fakulta tělesné výchovy a sportu, Univerzita Karlova v Praze
}

\begin{abstract}
Abstrakt
Pohybová aktivita do určité míry ovlivňuje tělesné složení a stavbu těla. Záleží především na druhu sportovní zátěže a na sportovní specializaci konkrétního jedince. Obecně platí, že čím delši dobu se jedinec danému sportu věnuje, tím je toto ovlivněni vyšši Vrcholoví sportovci tedy z tohoto pohledu vytvárejé selektovanou skupinu jedinců s typickými somatickými znaky charakteristickými pro daný sport (Přidalová \& Zapletalová 1997).

Cílem této studie bylo zjistit tělesné složení předních českých závodníků v řecko-římském zápase. Dále jsme zjištovali segmentální rozložení tekutin v těle u jednotlivých probandů a tím tedy vliv zápasu na symetrický rozvoj těla.

Celkem bylo otestováno 12 probandů v prưměrném věku 22,0 0 5,8 let. Tělesné složení i segmentální rozložení tekutin jsme zjištovali pomoci multifrekvenčního bioimpedančního analyzéru InBody 3.0.

Ziskaná data ukazuji na vysoké zastoupeni aktivni hmoty (FFM) a buněčné hmoty (BCM) a zároveñ nizké zastoupeni neaktivni tukové hmoty (FM) v porovnání s běžnou populací. Zjištěná byla vysoká afinita buněčné hmoty (BCM) k bazálnímu metabolismu (BMR) $(r=0,910)$.

Na základě našich výsledků můžeme konstatovat, že zápas je vhodná sportovní aktivita pro rozvoj svalstva celého těla a tento rozvoj je symetrický pro obě poloviny těla. Při porovnání s normami pro běžnou populaci jsme zjistili vysoké zastoupeni svalové hmoty na hornich končetinách a také v oblasti trupu.
\end{abstract}

\begin{abstract}
Physical activity affects body composition. It depends on the type of sports strain and sports specialization. Generally, the effect increases with time of implementation of particular sport. Top athletes make selected group of individuals with typical somatic features characteristic of the sport (Pridalová \& Zapletalová 1997).

The aim of this study was to determine the body composition of top Czech athletes in Greco-Roman wrestling. We also investigated the segmental distribution of fluid in the body of each of the probands and thus influence the Greco-Roman wrestling at the symmetrical development of the body. Totally we tested 12 probands with a mean age of $22.0 \pm 5.8$ years. Body composition and segmental distribution of fluid was examined using multifrequent bioimpedancy analyzer InBody 3.0.

The results show a high proportion of the active mass (FFM) and cell mass (BCM) and the low proportion of inactive fat mass (FM) compared with the general population. We found a high affinity cell mass (BCM) to basal metabolic rate $(B M R)(r=0,910)$.

Based on our results we can say that Greco-Roman wrestling is a sport suitable for the muscles development of whole the body and this development is balanced for both sides of the body. We also found high proportion of muscle mass in the upper extremities and the trunk with comparison with the general population.
\end{abstract}

Klíčová slova: řecko-řimský zápas, tělesné složení, distribuce tělesných tekutin

Keywords: Greco-Roman wrestling, body composition, body water distribution

\section{ÚVOD}

Vliv pohybové aktivity na tělesné složení dosud není dostatečně prozkoumán, ale je stále v oblasti zájmu. Z krátkodobých studií však vyplývá, že sportovní zatížení má pozitivní vliv na obvodové rozměry, což souvisí 
s rozvojem daných svalových partií. Na tělesné složení je třeba nahlížet individuálně, může se měnit v závislosti na věku, pohlaví, tělesné aktivitě a sportu, somatotypu, genetice, silná je i individuální variabilita. Přesto má určení složení těla mnohostranný význam a je v poslední době často nedílnou součástí sportovní diagnostiky.

Kromě fyziologického profilu nám mohou informace o tělesném složení pomoci k odhadu optimální tělesné hmotnosti sportovce, optimálního poměru aktivní a tukové hmoty pro konkrétní sportovní disciplínu a také v určitých sportech pro zařazení do soutěžní hmotnostní kategorie (např. zápas, judo, box, kulturistika atd.). Dále pro sportovce může být měření tělesného složení a sledování jeho změn významným přínosem nejen ve smyslu určení přiměřené tělesné hmotnosti pro období závodu či soutěže, ale i pro hodnocení efektu tréninkového procesu (Sinning 1996; Ishiguro et al., 2005).

V zápase je dominantní složkou úroveň svalové síly. Ta je do značné míry determinována také tělesným složením, tedy zastoupením využitelné aktivní hmoty. Podle Andreoli et al. (2003) je měření buněčné hmoty (BCM) nejlepším prediktorem svalové účinnosti, který může predikovat sportovní výkon. V zápase, stejně jako v dalších bojových sportech, je nejčastější způsob snižování tělesné hmotnosti dehydratace organismu, resp. rychlé redukování hmotnosti je spojené nejen se snížením tukové složky, ale i s nežádoucím snížením složky aktivní (Forbes, 1987; Proteau et al., 2006). Informace o tělesném složení tedy může být indikátorem nutričního stavu sportovce, ale taktéž může poskytnout informace o aktuální homeostáze tekutin v těle (Andreoli et al., 2003).

Je typické, že vrcholoví sportovci a fyzicky aktivní jedinci mají jiný poměr tukové a netukové hmoty než jedinci se sedavým způsobem života, bez ohledu na pohlaví (Heyward, 1996). Cílem naší studie bylo zjistit tělesné složení u předních českých závodníků v řecko-římském zápase.

Zápas charakterizujeme jako individuální úpolový sport, ve kterém dva zápasníci - soupeři stejné hmotnostní a věkové kategorie - vedou boj, ve kterém se za pomoci technických činností, síly, vytrvalosti a rychlosti snaží podle pravidel zvítězit položením soupeře na lopatky nebo získáním bodové převahy. Činnost zápasníka vyžaduje velkou úroveň rychlostně - silových, kondičních a koordinačních schopností, dostatečnou vytrvalost potřebnou k tréninku, protože sportovní př́prava zápasníků je vykonávána velmi intenzivně (Ďurech, 2003). Sportovní výkon v zápase tedy vyžaduje vysoké rezervy anaerobní vytrvalosti a kapacity s dobrou úrovní aerobního systému. Z pohybových schopností sehrává při zápase důležitou úlohu síla, především vytrvalost v dynamické síle a statická síla trupu a paží. Obratnost jako další z pohybových schopností se rozvíjí ve vztahu k technice chvatu a projevuje se ve variabilitě, přizpůsobivosti techniky odlišnému vzrůstu, pohybovým návykům a dalším vlastnostem soupeře. Ve sportovní přípravě zápasníků, kromě péče věnované zdokonalování př́islušného pohybového programu, při kterém se jedná o sladění svalových kontrakcí různých typů v př́islušných svalových skupinách, svalech či jejich částech, je trénink zápasníků zaměřen na rozvoj maximální síly, rychlosti, vytrvalosti a obratnosti (Havlíčková, 1993).

\section{METODIKA}

Výzkumný soubor tvořili přední čeští závodníci v řecko-římském zápase různých hmotnostních kategorií účastnící se mezinárodních a nejvyšších národních soutěží. Celkem bylo otestováno 12 mužů (průměrný věk = $22,0 \pm 5,8$ let, tělesná výška $=171,2 \pm 7,1 \mathrm{~cm}$, tělesná hmotnost $=74,8 \pm 14,8 \mathrm{~kg}, \mathrm{BMI}=25,3 \pm 3,7 \mathrm{~kg} \cdot \mathrm{m}^{-2}$ ).

Tělesná výška byla stanovena $\mathrm{s}$ přesností na $0,1 \mathrm{~cm}$, tělesná hmotnost byla měřena pomocí osobní elektronické váhy s přesností na $0,1 \mathrm{~kg}$. Tělesné složení a segmentální rozložení tekutin a tím tedy rozložení svalové hmoty v horních a dolních končetinách a trupu, jako jednoho z pomocných ukazatelů symetrie tělesného zatížení, jsme zjišt’ovali pomocí multifrekvenčního bioimpedančního analyzéru InBody 3.0.

InBody použivá 8 dotykových elektrod, jimiž je do těla vpouštěn proud o různých frekvencích, díky čemuž získáváme 5 různých impedancí pro trup a zvlášt’ pro každou ze čtyř končetin. Touto hloubkovou analýzou InBody lze dosáhnout stanovení celkového tělesného složení a je jí také možno měřit svalovou hmotu v jednotlivých tělesných částech. Pomocí těchto parametrů lze diagnostikovat asymetrické složení těla, případné svalové dysbalance nebo zranění v daných částech těla.

Pro popis souboru jsme použili základní statistické charakteristiky (aritmetický průměr, směrodatná odchylka, Pearsonův korelační koeficient). K porovnání výsledků distribuce tekutin mezi pravou a levou stranu těla a tím tedy ke zjištění míry tělní symetrie jsme použili párový t-test. 


\section{VÝSLEDKY}

Průměrná hodnota aktivní tělesné hmoty (LBM) činila $64,63 \pm 12,82 \mathrm{~kg}$. Svalová hmota $(\mathrm{MM}) \mathrm{z}$ toho činila $60,58 \pm 12,13 \mathrm{~kg}$ a buněčná hmota $(\mathrm{BCM}) 45,65 \pm 9,0 \mathrm{~kg}$. Ve sledovaném souboru jsme zaznamenali průměrnou hodnotu celkového tuku v těle (FM) $9,73 \pm 3,39 \mathrm{~kg}$, což bylo v procentuálním vyjádření průměrně $12,98 \pm 3,37 \%$ tělesné hmotnosti. Co se týče tekutin v těle, průměrné množství celkové tělesné vody bylo 47,53 $\pm 9,561$, přičemž průměrná hodnota intracelulární tekutiny (ICW) byla 32,63 $\pm 6,43$ la průměrná hodnota extracelulární tekutiny $(\mathrm{ECW})$ byla 14,92 $\pm 3,18$ 1. Proteinová hmota činila v průměru 13,03 $\pm 2,57 \mathrm{~kg}$ a průměrná hmotnost kostry byla 4,04 $\pm 0,69 \mathrm{~kg}$. Hodnota bazálního metabolismu (BMR) byla průměrně 2027,75 $\pm 226,58 \mathrm{kcal}$.

Tab. 1 Jednotlivé parametry tělesného složení. Hodnoty jsou uvedeny ve tvaru průměr $\pm S D$.

\begin{tabular}{|c|c|c|c|}
\hline \multirow{2}{*}{} & Průměr \pm SD & Min. hodnota & Max. hodnota \\
\cline { 2 - 4 } & $64,63 \pm 12,82$ & 44,60 & 96,80 \\
\hline LBM [kg] & $60,58 \pm 12,13$ & 41,60 & 91,00 \\
\hline MM [kg] & $9,73 \pm 3,39$ & 4,50 & 16,20 \\
\hline FM [kg] & $12,98 \pm 3,37$ & 6,30 & 18,10 \\
\hline FM [\%] & $47,53 \pm 9,56$ & 32,60 & 71,60 \\
\hline TBW [1] & $32,63 \pm 6,43$ & 22,60 & 48,60 \\
\hline ICW [1] & $14,92 \pm 3,18$ & 10,00 & 23,00 \\
\hline ECW [1] & $13,03 \pm 2,57$ & 9,00 & 19,40 \\
\hline Protein Mass [kg] & $4,04 \pm 0,69$ & 2,96 & 5,76 \\
\hline Bone Mass [kg] & $45,65 \pm 9,00$ & 31,60 & 2388,90 \\
\hline BCM [kg] & $2027,75 \pm 226,58$ & 1629,50 & \\
\hline BMR [kcal] & & & \\
\hline
\end{tabular}

Legenda:
LBM - Lean Body Mass
MM - Muscle Mass
FM - Fat Mass
TBW - Total Body Water
ICW - Intracellular Water
ECW - Extracellular Water
BCM - Body Cell Mass
BMR - bazální metabolismus

Pomocí př́stroje InBody 3.0 jsme také sledovali segmentální rozložení celkové tělesné vody (TBW) v končetinách a trupu. Na horních ani na dolních končetinách jsme nezjistili žádné významné rozdíly v distribuci tekutin mezi pravou a levou polovinou těla, objem tekutin byl tedy symetrický i při individuální dominanci končetin jednotlivých probandů. U horních končetin jsme naměřili průměrně $3,23 \pm 0,821$ u pravé a $3,24 \pm$ 0,821 u levé končetiny $(\mathrm{p}<0,05)$. U dolních končetin to bylo $7,15 \pm 1,331$ na pravé a $7,15 \pm 1,301$ na levé končetině $(p<0,05)$ (rozmezí jednotlivých hodnot viz tab. 2). U trupu jsme zjistili průměrné množství tekutiny $23,68 \pm 4,671$, u jednotlivých probandů se tato hodnota pohybovala v rozmezí od 16,0 1 do 35,1 1 . 
Tab. 2 Segmentální rozloženi tělesných tekutin měrené bioimpedančním př́strojem InBody 3.0. Hodnoty jsou uvedeny ve tvaru průmér $\pm S D$.

\begin{tabular}{|l|l|c|c|c|}
\hline \multirow{2}{*}{\multicolumn{2}{|c|}{}} & \multicolumn{3}{|c|}{ MUŽI (n=12) } \\
\cline { 2 - 5 } \multicolumn{2}{|c|}{} & Průměr \pm SD & Min. hodnota & Max. hodnota \\
\hline TBW [1] & PHK & $37,53 \pm 9,56$ & 32,60 & 71,60 \\
\hline \multirow{4}{*}{$\begin{array}{l}\text { Segmentální } \\
\text { rozložení } \\
\text { tekutin } \\
{[1]}\end{array}$} & LHK & $3,24 \pm 0,82$ & 1,87 & 5,24 \\
\cline { 2 - 5 } & Trup & $23,68 \pm 4,67$ & 1,88 & 5,24 \\
\cline { 2 - 5 } & PDK & $7,15 \pm 1,33$ & 16,00 & 35,10 \\
\cline { 2 - 5 } & LDK & $7,15 \pm 1,30$ & 5,15 & 10,42 \\
\hline Edema exam & & $0,313 \pm 0,01$ & 0,299 & 0,326 \\
\hline
\end{tabular}

\section{Legenda:}
PHK - pravá horní končetina
LHK - levá horní končetina
PDK - pravá dolní končetina
LDK - levá dolní končetina

Přístroj InBody měří tělesnou vodu jejím rozdělením do nitrobuněčné a mimobuněčné vody a pro výpočet rovnováhy tělesné vody používá index otoku (edema exam). Rozsah normy pro index otoku (ECW/TBW) je mezi 0,30 a 0,35 . U našeho souboru byl naměřen průměrný index otoku (edema exam) $0,313 \pm 0,01$, což je v mezích normy. Pouze u jednoho z probandů byl tento index mimo rozmezí normy, ale pouze o 0,001 , což je nepatrný výkyv.

\section{DISKUSE}

Podmíněnost sportovního výkonu v zápase množstvím aktivní tělesné hmoty a předsoutěžní redukce tělesné hmotnosti spojená velmi často s dehydratací, př́ípadně s nežádoucím snížením i aktivní hmoty spolu s tukovou složkou, poukazuje na význam sledování tělesného složení u aktivních zápasníků, přinejmenším alespoň v soutěžním období. Aktivní složka, LBM (Lean Body Mass), definována denzitou menší jak 1,100 g.cm- ${ }^{3}$ a obsahem esenciálního tuku (Lohman, 1992) činila ve sledovaném souboru zápasníků 64,63 $\pm 12,82 \mathrm{~kg}$. Tento parametr se považuje za důležitý předpoklad pro výkon v zápase nebo dalších úpolových sportech tím, že zahrnuje všechny tkáně v těle kromě depotního tuku a má v porovnání s celkovou tělesnou hmotností užší vztah k řadě fyziologických parametrů jako je spotřeba kyslíku, minutový srdeční objem, vitální kapacita plic atd. (Pařízková, 1973). Je závislý na genetice, ale je možné ho rozvíjet pohybovou aktivitou a výživou. Průměrná hodnota LBM u našich probandů $(64,63 \pm 12,82 \mathrm{~kg})$ je srovnatelná s dostupnou literaturou, konkrétně se zápasníky z americké univerzity ( $\mathrm{n}=18$, průměrný věk $=21,0$ let), kde byla naměřena hodnota LBM průměrně $64,85 \mathrm{~kg}$ (Finn, 2003). Je třeba zmínit, že soubor tvořili závodníci různých hmotnostních kategorií (nejlehčí závodník vážil 50,5 kg, nejtěžší 109,6 kg), proto je u jednotlivých parametrů hodnota směrodatné odchylky vysoká.

Dalším důležitým parametrem tělesného složení je množství tělesného tuku. Zde se názory trenérů na vhodné procentuální zastoupení rozcházejí. Někteří trenéři tuk prosazují jako vhodný zdroj energie při dlouhotrvajících činnostech, jiní považují tuk za nežádoucí a snaží se ho minimalizovat. Avšak tuk základní (esenciální, strukturní), který je součástí orgánů (kostní dřeň, srdce plíce, ledviny, mozek, atd.), je nepostradatelný pro správnou funkci organizmu a tuk zásobní (depotní) má svojí úlohu v ochraně orgánů a izolaci tělesného tepla (Malá, 2008). 
V našem souboru jsme zjistili průměrné množství tělesného tuku $9,73 \pm 3,39 \mathrm{~kg}$, což v procentuálním vyjádření znamenalo 12,98 $\pm 3,37$ \% tělesné hmotnosti. Vardaz (2007) zjistil u souboru 8 elitních zápasníků průměrné množství tuku 9,7 $\pm 6,3$ \%, Finn (2003) naměřil u souboru 18 zápasníků průměrně 10,55 kg tuku. Zjištěný výsledek našeho souboru odpovídá doporučovanému množství tuku pro zápasníky, které se pohybuje v rozmezí 5-16\%. Zde je ale nutné připomenout, že je třeba také dbát na metodu měření, bioimpedanční metoda nerozlišuje množství podkožního a depotního tuku, je možné zjistit pouze celkové zastoupení tělesného tuku v organismu.

Sledování množství celkové tělesné vody (TBW) a její rozdělení na intracelulární (ICW) a extracelulární (ECW) je důležité především v souvislosti s předsoutěžním snižování tělesné hmotnosti. Nejčastější způsoby redukce tělesné hmotnosti jsou založeny na principu dehydratace, čehož je dosahováno restrikcí prř́jmu tekutin a potravin v kombinaci se zvýšením pohybové aktivity a to často ve speciálních gumových oblecích nebo ve více vrstvách oblečení. Výjimkou není ani použití sauny. Tyto postupy ale mohou mít řadu negativních dopadů nejen na momentální výkon a zdraví závodníka, ale mohou mít negativní dopady na celkové zdraví i v dlouhodobém časovém horizontu. V př́ípadě, že je tělesná hmotnost snižována rychle a výrazně, zvyšuje se nejen riziko úrazů, ale i řady onemocnění. Z negativních dopadů rapidní redukce tělesné hmotnosti na fyzickou stránku organismu můžeme uvést nárůst tepové frekvence, zhoršení oběhových a dýchacích funkcí, porucha termoregulačních pochodů s rizikem přehřátí, pokles průtoku krve ledvinami a tím možnost usazování některých látek v ledvinách a v neposlední řadě také pokles množství solí v organismu. Snížení množství obíhající krve se projevuje snížením výkonnosti srdce při maximálním i středním výkonu. To vede také ke snížení svalové síly a tím klesá i doba, po kterou je sportovec schopen podávat intenzivnější výkony (Nedorostová, 1977). Jak extrémní následky může taková redukce tělesné hmotnosti před soutěží mít, dokládá př́ípad tří mladých amerických zápasníků, kteří v roce 1997 zemřeli na hypertermii a dehydrataci. Tato tragická událost se týkal úmyslného rychlého snížení hmotnosti, protože všichni tři sportovci byli zápasníci připravující se na soutěž. Bohužel stále je předsoutěžní rapidní redukce tělesné hmotnosti velice častý jev a dokonce se s ní setkáváme i u mladých sportovců, což dokazuje řada studií. Kinigam a Gorenflo (2001) zjistili, že více než 77\% mladých amerických zápasníků snižuje svojí tělesnou hmotnost o více než 2,27 kg, další studie (Brownell, 1987) uvádí, že britští zápasníci a boxeři redukují svojí hmotnost v rozmezí 5-10\% původní hmotnosti. Jsou také príípady, kdy závodník měl hmotnostní úbytek o více než 18\% za jeden týden (Szyguła, 2006).

Další parametry (Bone Mass, Protein Mass) je vhodné sledovat spíše z dlouhodobého hlediska. Dlouhodobé studie naznačují, že fyzicky aktivní jedinci mají vyšší obsah kostních minerálů, denzitu těla a více hmoty kosterních svalů (Heyward \& Stolarczyk, 1996).

Co se týče distribuce tekutin $\mathrm{v}$ těle, nezjistili jsme žádné rozdíly mezi pravou a levou stranou těla a to jak v případě horních, tak i v případě dolních končetin $(\mathrm{p}<0,05)$. Můžeme tedy konstatovat, že tělesná aktivita zápas je vhodným prostředkem pro všeobecně silový rozvoj organismu a v prípadě bilaterálního vykonávání technik rozvíjí symetricky obě poloviny těla.

\section{ZÁVĚRY}

Sledování změn v jednotlivých komponentách tělesného složení u předních závodníků v řecko-římském zápase by mohlo poskytnout informace o vlivu zápasu na organismus, především tukovou a svalovou složku. Průběžné sledování zastoupení tukové a svalové složky má také význam při časté redukci tělesné hmotnosti $\mathrm{s}$ cílem soutěžit v nižší hmotnostní kategorii než je aktuální. Při nejčastějším způsobu tohoto nárazovitého snižování hmotnosti závodníka před soutěží, snižování tělesné hmotnosti za pomoci ztrát vody dehydratací, je možné, že dojde nejen ke snížení celkové vody v těle, ale i ke snížení tukové složky spolu se složkou aktivní (Forbes, 1987). Změny v tukuprosté hmotě (FFM) se mohou projevit snížením svalové síly a tím klesá i doba, po kterou je sportovec schopen podávat intenzivnější výkony. Sledováním změn zastoupení svalové a tukové tkáně, tedy tělesného složení, má význam především ve smyslu zamezení negativního dopadu redukce tělesné hmotnosti na výkonnost a zdraví závodníka. Tyto informace mohou být velmi cenné při úpravě stravovacího a tréninkového programu při redukci tělesné hmotnosti.

Naše výsledků dále ukazují, že zápas je vhodná sportovní aktivita pro rozvoj svalstva celého těla a tento rozvoj je symetrický pro obě poloviny těla. Ve srovnání s normami pro běžnou populaci jsme zjistili vysoké zastoupení svalové hmoty na horních končetinách a také v oblasti trupu.

Zjištění typického tělesného složení úspěšných závodníků nám také může pomoci například při výběru talentů nebo při výskytu určitých dysbalancí. 
STUDIA SPORTIVA 2012/6, č. 2, s. 126-131

Řešeno s podporou Výzkumného záměru MŠMT ČR MSM 0021620864 a Specifického vysokoškolského výzkumu 2012-265 603.

\section{Literatura}

ANDREOLI, A., MELCHIORRI, G., BROZZI, M., MARCO, A.D.,VOLPE, S.L. et al. (2003). Effect of different sports on body cell mass in highly trained athletes. Acta Diabetol 40, 122-125.

BROWNELL, K.D., STEEN, S.N., WILMORE, J.H.(1987). Weight regulation practise in athletes: analysis of metabolic and health effects. Medicine and Science in Sports and Exercise. 19: 546-556.

ĎURECH, M.: (2003) Silová príprava v zápasení. 1 vyd. Bratislava: PEEM.

FINN, K.J., LUND, R., ROSENE, M. (2003)Glutamine supplementation did not benefit athletes during short-term weight reduction. Treadwell Journal: Journal of Sports Science and Medicine, 2003, Vol. 2, 163-168. FORBES, G.B. (1987). Human body composition. Springer Verlag: New York.

HAVLÍČKOVÁ, L. a kolektiv.: (1993) Fyziologie tělesné zátěže II., speciální část 1. díl. 1. vyd. Praha: Karolinum.

HEYWARD, V.H., STOLARCZYK, L.M. (1996). Applied body composition assessment. Human Kinetics: Champaign.

ISHIGURO, N. et al. (2005). A comparison of three bioelectrical impedance analyses for predicting lean body mass in a population with a large difference in muscularity. Eur. J. Appl. Physiol., r. 94, č. 1-2, s. 25-35.

KINIGHAM, R.B., GORENFLO, D.W. (2001) Weight loss methods of high school wrestlers. Medicine \& Science in Sports \& Exercise, 2001; 33(5): 810-813.

LOHMAN, T.G. (1992). Advances in Body Composition Assessment. Human Kinetics: Champaign.

MALÁ, L., MALÝ, T. \& ZAHÁLKA F. (2008). Profil telesného zloženia juniorských reprezentantov v jude. Česká kinantropologie, Vol. 12, č. 3, s. 94 -103.

NEDOROSTOVÁ, J. (1197) Shazování váhy. Československý sport.

PAŘíZKOVÁ, J. (1973). Složeni těla a lipidový metabolismus za různého pohybového režimu.

1.

vyd., Praha: Avicenum.

PROTEAU, S., PELlE, A., COLLOMP, K., BENHAMOU, L., COURTEIX, D. (2006). Bone

Density in Elite Judoists and Effects of Weight Cycling on Bone Metabolic Balance. Medicine \& Science in Sports \& Exercise, Official Journal of the American College sf Sports Medicine, 694-700.

P̌̌IDALOVÁ, M. \& ZAPLETALOVÁ (1997): Tělesné složení a typologie lyžařů. In: Optimální pưsobení tělesné zátěže. Hradec Králové: Nakladatelství Gaudeamus.

SINNING, W.E. (1996). Body composition in athletes. In: Roche, A.F.; Heymsfield, S.B.; Lohman, T.G. (eds.) Human body composition. Human Kinetic, Champaign.

SZYGUŁA, Z. (2006) Nieprawidłowe praktyki żywieniowe i odwodnienie u sportowców. Medicina Sportiva Practica, 2006; 7(3): 35-40.

VARDAZ, S.A., TEZEL, S., ÖZTÜRK, L., KAYA, O. (2007) The relationship between body composition and anaerobic preformance of elite young wrestlers. Journal of Sports Science and Medicine, Vol. 6, 34-38. 